DEVELOPMENT OF MANAGEMENT AND ENTREPRENEURSHIP METHODS ON TRANSPORT, № 2 (75), 2021
РОЗВИТОК МЕТОДІВ

УПРАВЛІННЯ ТА ГОСПОДАРЮВАННЯ

НА ТРАНСПОРТІ, № 2 (75), 2021
УДК 519.85:656.61

JEL Classification C53,G31, M11, R49

DOI 10.31375/2226-1915-2021-2-89-107

\section{ОПТИМІЗАЦІЯ ВИКОРИСТАННЯ ВИРОБНИЧОЇ ПОТУЖНОСТІ СУДНОРЕМОНТНОГО ПІДПРИСМСТВА}

\section{О.Б. Гіріна}

к.е.н., доцент кафедри «Управління логістичними системами та проектами» olga.girina63@gmail.com

ORCID:http://orcid.org/0000-0001-5917-6551 С.О. Жигаловська

студентка навчально-наукового інституту морського бізнесу

Одеський національний морський університет, Одеса, Україна

Анотація. У статті розглянуті питання визначення виробничої потужності судноремонтного підприсмства (СРП) $і$ моделювання виробничого процесу судноремонту з використанням системного підходу. Запропоновані статична модель для оптимізації використання виробничої потужності СРП при виконанні планово-попереджувального ремонту суден судноплавної компанії в ринкових умовах $і$ динамічна модель річного плану з метою максимізаиії завантаження СРП і рівномірного використання його виробничої потужності. У проведених розрахунках контрольного прикладу на основі статичної моделі було отримано чотири оптимальних плани з різними умовами оптимізації: план використання виробничої потужності СРП із заданими початковими даними; план з максимальною виробничою потужністю при повному використанні ресурсів СРП; план при зміні платоспроможності судноплавної компанії; план при зміні строків та нормативів ремонту суден. У всіх планах проаналізований обсяг ремонту та наявність ресурсів, щчо лімітують виробничий прочес. На підставі запропонованих моделей виділено наступні групи факторів, від яких залежить використання виробничої потужності СРП:

1) техніко-експлуатаційні параметри підрозділів СРП;

2) попит на послуги СРП у вигляді обсягів планових робіт за видами виробничої діяльності; СРП;

3) нормативи використання потужностей

4) платоспроможсність замовників; 5) спосіб організації виробничого процесу.

Ключові слова: судноремонтне підприємство, виробнича потужність, економіко-математичні моделі, аналіз, групування чинників.

(С Гіріна О.Б., Жигаловська С.О., 2019
УДК 519.85:656.61

JEL Classification C53,G31, M11, R49

DOI 10.31375/2226-1915-2021-2-89-107

\section{ОПТИМИЗАЦИЯ ИСПОЛЬЗОВАНИЯ ПРОИЗВОДСТВЕННОЙ МОЩНОСТИ СУДОРЕМОНТНОГО ПРЕДПРИЯТИЯ}

\author{
О.Б. Гирина \\ к.э.н., доцент кафедры «Управление \\ логистическими системами и проектами» \\ olga.girina63@gmail.com \\ ORCID:http://orcid.org/0000-0001-5917-6551 \\ С.О. Жигаловская \\ студентка учебно-научного института \\ морского бизнеса \\ Одесский национальный морской университет, \\ Одесса, Украина
}

Аннотация. В статье рассмотрены вопросы определения производственной мощности судоремонтного предприятии (СРП) и моделирование производственного процесса судоремонта с использованием системного подхода.

Под производственной мощностью завода понимается максимально возможный годовой выпуск продукции в установленных для СРП показателях и номенклатуре при полном использовании оборудования и площадей. Максимальный объем производства достигается при полном соответствии структуры выпускаемой продукиии со структурой производственных ресурсов и структурой производственных фондов.

Нахождение оптимальных решений требует практического использования моделей оптимизации в управлении производством. Предложена статическая модель для оптимизации использования производственной мощности СРП при исполнении планово-предупредительного ремонта судов пароходства в рыночных условиях и динамическая модель годового плана с иелью максимизачии загрузки СРП и равномерного использования его производственной мощности.

На основании предложенных моделей выделены следующие группь факторов, от которых зависит использования производственной мощчности СРП:

1) технико-эксплуатационные параметры подразделений СРП;

2) спрос на услуги СРП в виде объемов плановых работ по видам производственной деятельности;

СРП;

3) нормативы использования мощяностей

4) платежеспособность заказчиков; прочесса.

5) способ организации производственного

Ключевые слова: судоремонтное предприятие, производственная мочность, экономикоматематические модели, анализ, группировка факторов 
UDC 519.85:656.61

JEL Classification C53,G31, M11, R49

DOI 10.31375/2226-1915-2021-2-89-107

\title{
OPTIMIZATION OF THE USE OF THE PRODUCTION CAPACITY OF A SHIPYARD
}

\author{
Olga Girina \\ Ph.D., associate Professor of Department of «Management of Logistics Systems and Projects» \\ ORCID: http://orcid.org/0000-0001-5917-6551
}

\section{Svetlana Zhigalovskaya}

The student of the educational and scientific institute of maritime business Odessa National Maritime University, Odessa, Ukraine

\begin{abstract}
The article discusses the issues of determining the production capacity of a shipyard and modeling the production process of ship repair using a systematic approach. The production capacity of the plant is understood as the maximum possible annual output in terms of the indicators and nomenclature established for the shipyard, with the full use of equipment and areas. The maximum volume of production is achieved when the structure of products is fully consistent with the structure of production resources and the structure of production assets.

Improvement of management at the ship repair enterprise can be carried out in directions, including by creation of the model of production based on allocation of its most essential characteristics, used of mathematical methods of optimization. A static model is proposed to optimize the use of the shipyard production capacity, when performing scheduled preventive maintenance of shipping company ships in market conditions and a dynamic model of the annual plan in order to maximize the shipyard load and uniform use of its production capacity. In the performed calculations of the test case on the basis of the static model, four optimal plans with different optimization conditions were obtained: a plan for using the production capacity of the shipyard with the given initial data; plan with maximum production capacity with full use of shipyard resources; a plan for changing the solvency of the shipping company; plan for changing the terms and standards of ship repair. In all plans, the volume of repairs and the availability of resources limiting the production process are analyzed.

Based on the proposed models, the following groups of factors on which the use of the production capacity of the shipyard depends have been identified:

1) technical and operational parameters of shipyard units,

2) demand for shipyard services in the form of volumes of planned work by type of production activity;

3) standards for the use of shipyard capacities;

4) the solvency of customers;

5) the way of organizing the production process.

The method of organizing ship repair is understood as fixing of certain resources of the shipyard units for the fulfillment of planned or additional customer orders. All factors of the first four groups affect the volume of ship repair and other indicators of the production program in terms the actual or optimal way of organizing production.
\end{abstract}

Key words: shipyard, production capacity, economic and mathematical models, analysis, grouping of factors 
DEVELOPMENT OF MANAGEMENT

AND ENTREPRENEURSHIP METHODS ON TRANSPORT, № 2 (75), 2021
РОЗВИТОК МЕТОДІВ

УПРАВЛІННЯ ТА ГОСПОДАРЮВАННЯ

НА ТРАНСПОРТІ, № 2 (75), 2021
Постановка проблеми. Темпи розвитку виробничих потужностей судноремонтних підприємств в Україні значно відстали від рівня розвитку флоту. Скорочення часу знаходження в ремонті і підвищення якості ремонтних робіт - один 3 основних шляхів підвищення рентабельності роботи флоту. Удосконалення управління на судноремонтному підприємстві може здійснюватися в різних напрямках, в тому числі шляхом створення моделі виробництва, заснованої на виділенні найбільш суттєвих його характеристик, використання математичних методів оптимізації, обробки інформації за допомогою технічних засобів [1]. Ці напрямки досліджень являються актуальними, тому що дозволяють підвищити ефективність роботи транспорту та судноремонту.

Огляд останніх досліджень та публікацій. У зазначеному комплексі питань важливу роль відіграє підвищення організації і культури судноремонтного виробництва, а саме: вдосконалення нормативно-технічної документації на ремонт, впровадження індустріальних методів ремонту і прогресивних технологічних процесів, впровадження прогресивних форм організації виробництва; комплексна механізація і автоматизація виробництва; вдосконалення технічного стану обладнання та контролю якості продукції [2].

У роботі [3] обгрунтовується доцільність визначення величини натурального показника виробничої потужності як суми показників виробничої потужності всіх окремих видів або систем виробництва в установлений період продуктивного часу. Багатофакторний логіко-математич- ний алгоритм моделювання технологічних процесів розроблений для оперативного плану виробництва за фактичною виробничою потужністю СРП 3 використанням виробничої функції. Цей метод проектування виробничої функції та розробки планових показників застосовується при постійному показнику виробничої потужності СРП. В цьому випадку необхідно враховувати, що дійсна величина даного показника незмінна і не знаходиться у функціональній залежності від дискретної частки підприємства в обсязі платоспроможного попиту будь-якого 3 секторів галузевого ринку. Наступним за значимістю критерієм стає коректність обліку періоду часу для існування цієї частки.

Слід підкреслити, що виходячи 3 цих критеріїв, встановлюються ознаки для ідентифікації оптимальних співвідношень факторів праці і виробничого капіталу. При їх правильному, тобто оптимальному співвідношенні, техніко-технологічна структура видів і систем виробництва СРП буде забезпечувати заданий виробничий результат 3 мінімальними витратами або максимальний ефект при заданому обсязі ресурсів. Будь-який вид або система виробництва СРП нерозривно пов'язана 3 кон'юнктурою цін на галузевому ринку і з кон'юнктурою цін на ринках ресурсів.

Для ринкового компонування структури систем виробництва СРП характерні два відмінних принципи:

1. Принцип деталізації виробничої програми по мікроекономічним підсистемам. Вартість реалізації проекту (замовлення) визначається як сума вартостей наборів деталізованих 
DEVELOPMENT OF MANAGEMENT

AND ENTREPRENEURSHIP METHODS ON TRANSPORT, № 2 (75), 2021
РОЗВИТОК МЕТОДІВ

УПРАВЛІННЯ ТА ГОСПОДАРЮВАННЯ

НА ТРАНСПОРТІ, № 2 (75), 2021 витрат праці і капіталу в окремих видах і системах техніко-технологічної структури СРП.

Виробнича програма СРП структурується по управлінням різної форми власності і різних типів, класів, рангів суден і капіталу, що замовляють ремонтні роботи.

2. Другий принцип - це принцип аналогового моделювання. Реалізація цього принципу дає можливість управлінню СРП привести до порівнянності розмірність величини витрат праці i капіталу в обсягах виробництва, виміряти або оцінити потенціал своєї частки в торговому сегменті галузевого ринку в натуральному вираженні, після чого визначити рівень своєї реальної платоспроможності в дискретній частці свого обсягу попиту і кон'юнктурі цін в торговому сегменті галузевого ринку. [3,С.152]

У спеціальному випуску [4] пояснюється, як і чому європейські морські держави вдалися до виконання судноремонту і суднобудування за кордоном, і як ця діяльність 3 усіх боків виправдовує переоцінку глобального впливу суднобудування в усьому світі і того впливу, яке воно зробило на визначення заморських імперій.

У роботі [5] відзначається, що вплив конкуренції на галузь судноремонту посилився внаслідок основних характеристик галузі. Інтенсивність праці і капіталовкладень в промисловість викликає конкуренцію між центрами судноремонту, щоб забезпечити більш стабільний дохід. Проведене дослідження [5] було направлено на виявлення основних факторів конкуренції в судноремонтної промисловості. Це такі проблеми: низькі ціни на сталеві вироби, морська торгівля, віковий склад світового флоту, умови ставок фрахту і цін в суднобудуванні, ринки уживаних товарів і металобрухту.

У статті [6] представлений стратегічний бізнес-аналіз ремонтних робіт 3 використанням бізнес - матриці верфі, в результаті якого на основі аналізу внутрішніх і зовнішніх стратегічних факторів верфі показано, що національні верфі менш конкурентоздатні в порівнянні зі своїми потенційними конкурентами в регіоні. Модель була розроблена на основі внутрішніх і зовнішніх стратегічних факторів. Двадцять внутрішніх факторів (змінні) і двадцять зовнішніх факторів були вивчені 3 використанням екологічної моделі й конкурентних переваг. Внутрішні чинники складаються 3 матеріальних і нематеріальних ресурсів, а зовнішні чинники складаються 3 виробничого середовища і національного середовища. Дані були проаналізовані з використанням багатовимірного статистичного методу (факторного аналізу).

При дотриманні високої якості і низької собівартості ремонту судна судноремонтним підприємствам життєво важливо забезпечити мінімальні технологічно допустимі терміни від запуску до випуску судна 3 ремонту. Це завдання може бути вирішене, як відомо, при наявності чіткої системи організації та управління всіма видами виробничих ресурсів (в тому числі трудовими) iз застосуванням сучасних економіко-математичних методів.

Цей підхід дає можливість відповісти ще на одне важливе питання: а чи не пов'язано недовантаження, неповне використання трудових ре- 
DEVELOPMENT OF MANAGEMENT

AND ENTREPRENEURSHIP METHODS ON TRANSPORT, № 2 (75), 2021
РОЗВИТОК МЕТОДІВ

УПРАВЛІННЯ ТА ГОСПОДАРЮВАННЯ

НА ТРАНСПОРТІ, № 2 (75), 2021 сурсів 3 втратою обсягу виробництва СРП? [ 7]

Як показник ефективності використання виробничої потужності СРП в роботі [8] розглядається фондовіддача. Під виробничою потужністю заводу розуміється максимально можливий річний випуск продукції у встановлених для СРП показниках i номенклатурі при повному використанні обладнання і площ. Можливо, більш повне використання виробничої потужності СРП не тільки характеризує завантаження основних виробничих фондів (ОВФ) заводу, що саме по собі надзвичайно важливо для його успішного функціонування, а й побічно пов'язане 3 ефективністю використання фондів флоту.

В якості узагальнюючих критеріїв аналізу виробничої потужності СРП використовуються два показники: використання виробничої потужності СРП в цілому і використання виробничої потужності по судноремонту. Перший - можна визначити наступним чином: річний випуск продукції СРП, згідно зі звітними даними заводу, в гривнях або в нормо-годинах, поділений на середньорічну виробничу потужність СРП в тому же вимірі. Відповідно другий показник коефіцієнт використання виробничої потужності по судноремонту розраховується шляхом поділу річного випуску продукції судноремонту в грн. або нормо-годинах на середньорічну виробничу потужність по судноремонту в тому же вимірі. Цей показник в найбільшій мірі, хоча і побічно, пов'язаний 3 показниками ефективності використання ОВФ флоту.

Основна ідея роботи [9] застосування системного підходу в розроб- ці механізму планування зниження витрат СРП. Автор відзначає високу частку трудових витрат, що мають складну структуру, через низький рівень механізації і малої автоматизації виробництва, високу частку ручних робіт, що виконуються в незручних суднових умовах (60-90\% загальної трудомісткості ремонту судна), наявність двох фронтів: внутрішнього (в цехах) і зовнішнього (безпосередньо на суднах). Управління витратами $\epsilon$ елементом управління ефективністю виробництва. В роботі [9] показано, що основний шлях підвищення зовнішньої продуктивності, а значить i зниження витрат СРП, полягає у зростанні пропускної здатності по ресурсомісткості виробничої програми по ресурсу, що лімітує час виконання даної програми в умовах, що склалися [9, С.162]. У зв'язку з тим, що час виконання виробничої програми частіше лімітує пропускна здатність СРП по трудомісткості, в роботі досліджено проблеми управління співвідношенням між продуктивністю праці i середньою заробітною платою.

Пропускна здатність підрозділів СРП по трудомісткості може бути визначена як трудомісткість робіт, яка вимірюється, наприклад, в кошторисних годинах, за програмою заданої структури, яку підрозділ здатний виконати за вибраний проміжок часу. 3 іншого боку, вона може бути визначена як час виконання однієї кошторисної години за програмою заданої структури.

Максимальний обсяг виробництва досягається при повній відповідності структури продукції, що випускається, зі структурою виробничих ресурсів і структурою фондів. 
DEVELOPMENT OF MANAGEMENT

AND ENTREPRENEURSHIP METHODS ON TRANSPORT, № 2 (75), 2021
РОЗВИТОК МЕТОДІВ

УПРАВЛІННЯ ТА ГОСПОДАРЮВАННЯ

НА ТРАНСПОРТІ, № 2 (75), 2021
Самим підбирати програму найбільш відповідної структури СРП не мають можливості через сезонність і нерівномірність завантаження ОВФ.

На великих СРП час виконання замовлень зазвичай визначається трьома провідними виробництвами (корпусним, механічним, трубопровідним). При цьому, для кожної конкретної програми, як правило, можна виділити два великих підрозділи, що належать до перерахованих виробництв та лімітують час виконання програми.

Знаходження оптимальних рішень вимагає практичного використання моделей оптимізації в управлінні виробництвом, без яких не може бути вирішено ряд завдань, наприклад, визначення умов отримання найбільшого (з урахуванням системності) ефекту від збільшення пропускної здатності. У зв'язку з цим в якості одного з блоків запропонованої моделі розроблена оптимізаційна модель, що дозволяє 3 певною точністю визначити оптимальні пропорції економічної системи в умовах, що склалися. У ринкових умовах оптимізацію прийняття рішень в реальних економічних системах доцільно розбивати на два етапи: спочатку намітити основні граничні пропорції шляхом розв'язання відповідних оптимізаційних задач, а потім забезпечити наближення до цих рішень, необхідне i можливе в умовах, що склалися [9].

У статті [10] відзначається зниження економічної стійкості СРП у зв'язку з наявністю збитків на підприємствах i мінімальним завантаженням їх потужностей.

У роботі [11] розглянуті головні положення методики визначен- ня виробничої спроможності СРП та ii удосконалення шляхом використання економіко-математичних методів для цих цілей. Розглянута теперішня практика цих розрахунків. Виробнича потужність СРП величина змінна, що залежить, зокрема, від співвідношення різних видів робіт, які формують виробничу програму підприємства. При наявності певного резерву потужності він може бути використаний для судноремонту, суднобудування, машинобудування та інших видів робіт, причому при зміні співвідношення між зазначеними видами робіт величина потужності змінюється.

Судноремонтні роботи, що визначають потужність по судноремонту, включають:

a) ремонт суден, що знаходяться на акваторії заводу, біля причалів або на суднопіднімальних спорудах (плановий судноремонт);

б) виготовлення змінно-запасних частин для ремонту суден;

в) навігаційний ремонт суден, що стоять біля причалів або на рейді;

г) виконання окремих замовлень для суден, що перебувають поза заводу: виготовлення замовлень нульового етапу, ремонт механізмів обмінного фонду.

3 огляду на різноманітний характер і номенклатуру продукції, що випускається, і неможливість ії кількісної оцінки порівнянними натуральними показниками, для розрахунку виробничої потужності використовують єдиний універсальний вимірювач кількості продукції, що випускається - нормативну (кошторисну) трудомісткість їі виготовлення. Надалі кошторисна трудомісткість транс- 
DEVELOPMENT OF MANAGEMENT

AND ENTREPRENEURSHIP METHODS ON TRANSPORT, № 2 (75), 2021
РОЗВИТОК МЕТОДІВ

УПРАВЛІННЯ ТА ГОСПОДАРЮВАННЯ

НА ТРАНСПОРТІ, № 2 (75), 2021 формується у вартість, в результаті виробнича потужність виражається у гривнах.

Найбільш важливим і складним елементом розглянутого в [11] математичного алгоритму розрахунків $\epsilon$ система нормативів витрат ресурсів $i$-го цеху (обладнання) на знімання одиниці j-тої продукції підприємства. Надалі в цій роботі розглядається модель загальної задачі лінійного програмування 3 цільовою функцією на максимум випуску продукції заводу і двома групами обмежень:

1) обмеження про обсяг використання ресурсів СРП, який не повинен перевищувати наявного обсягу цих ресурсів,

2) обмеження про те, щоб обсяг продукції, що випускається, був не менший заданої величини.

У роботі [12] для складання виробничої програми судноремонтного заводу використовується модель об'ємного календарного планування. Удосконалення моделей для розвитку, поточного та календарного планування виробничої діяльності СРП виконується у роботі [13]. У цих роботах використовуються динамічні моделі 3 булевими змінними, що дозволяє детальніше враховувати усі особливості складного виробничого процесу в умовах невизначеності.

У статті [14] розглянута математична система моделей, коли на середньостроковому рівні планування вирішується завдання оптимізації роботи флоту по максимуму співвідношення результати-витрати і ступеня присутності компанії на відповідному локальному ринку. На поточному рівні вирішується завдання розставлення суден по місцях ремонту за критерієм мінімуму витрат, а на оперативному - завдання максимально ефективного ремонту судна на відповідній ремонтній базі.

Пропонований в роботі [15] спосіб моделювання суднобудівних робіт складається 3 чотирьох кроків моделювання. Перший створює одиничну модель, яка включає продукти, процеси, ресурси та інформацію. Другий крок розробляє інтегрований мережевий процес для зв'язування одиничних моделей, згідно з відомістю матеріалів. Третій створює модель, засновану на процесах, яка описує виробничі процеси шляхом комбінування одиничних моделей. Четвертий крок генерує імітаційну модель, застосовуючи мережу Петрі до моделі, заснованої на процесах, яка аналізує продуктивність збірки суднових блоків та визначає взаємозв'язок процесу складання.

Треба відзначити, що в розглянутих дослідженнях, присвячених визначенню та аналізу використання виробничої потужності судноремонтного підприємства, показано залежність цього показника від наявних ресурсів і структури виробничої програми, яка виконується в конкретному проміжку часу у ринкових умовах. В багатьох роботах цей зв'язок упорядковується завдяки використанню оптимізаційних або статистичних методів та моделей, що робить розрахунки більш прогресивними та потребує наладки нормативної бази для їх автоматизації. Врахування ринкових умов у рамках системного підходу передбачає розглядати попит на послуги судноремонту та пропозицію цих послуг в одній задачі визначення та аналізу використання виробничої спро- 
можності СРП. Дослідження у цьому напрямку повинні, на наш погляд, супроводжуватися розвитком методики аналізу та поглибленням досвіду комп'ютерних розрахунків.

Завдання дослідження. У статті ставиться задача оптимізації використання виробничої потужності судноремонтного підприємства та іï аналізу за допомогою оптимізаційних методів та моделей. Впровадження результатів моделювання у практичній діяльності СРП може бути прискорене завдяки вдосконаленню методів аналізу розрахунків та експериментів.

Основний матеріал дослідження. Для цілей ефективного використання пропускної спроможності судноремонтного підприємства пропонується оптимізаційна модель поточного планування діяльності СРП. У постановці задачі судноплавна компанія має поставити у планово-попереджувальний ремонт деяку кількість своїх суден.

У таких умовах у якості параметрів управління обираються:

$X_{i}$ - кількість суден $i$-го типу, які будуть відремонтовані у плановому періоді.
У моделі прийняті наступні позначення:

$T_{k}$ - потужність у кошторисних годинах або нормо-годинах по виду ремонту $k$-го підрозділу судноремонтного підприємства;

$Q_{i \kappa}$ - обсяг ремонтних робіт судна $i$-го типу у $k$-му підрозділі судноремонтного підприємства (кошторисних годин або нормо-годин);

$N_{i}$ - кількість суден $i$-го типу у плановому судноремонті підприємства;

$R_{i}$ - витрати одного судна $i$-го типу під час ремонту;

$R$ - обсяг платоспроможного попиту судноплавної компанії.

В задачі розглядаються умови:

(1) - цільова функція на максимум відремонтованих суден;

(2) - обмеження на виробничу потужність $k$-го підрозділу;

(3) - обмеження на кількість суден у плановому ремонті ;

(4) - умови на обсяг платоспроможного попиту судноплавної компаніі;

(5) - умови невід'ємності змінних.

$$
\begin{gathered}
Z=\sum_{i=1}^{N_{i}} x_{i} \rightarrow \max \\
\sum_{i=1}^{N_{i}} Q_{i k} \cdot x_{i} \leq T_{k}, \forall k \in K \\
\sum_{i=1}^{N_{i}} x_{i} \leq N_{i}, i=\overline{1 ; N_{i}} \\
\sum_{i=1}^{N_{j}} R_{i} \cdot x_{i} \leq R \\
x_{i} \geq 0
\end{gathered}
$$


Робота СРП має сезонний характер та виконується в умовах невизначеності, тому для моделювання цих ускладнень більш підходить динамічна модель, в якій час враховується в явному вигляді.

Якщо розглядати ремонт суден як окремі замовлення, що розпочинають виконуватися в $j$-му місяці періоду T, то можна прийняти за параметр управління $x_{i j}=1$ булеву змінну, яка буде дорівнювати 1 , якщо $i$ - те замовлення починає виконуватися у $j$-му місяці. У протилежному випадку $x_{i j}=0$.

В моделі можна прийняти наступні позначення:

$$
T_{k}^{t} \text { - потужність у кошторисних }
$$
годинах по виду ремонту $k$-го підрозділу судноремонтного підприємства в періоді $t$;

$$
Q_{i j}^{k_{t}} \text { - обсяг ремонтних робіт } i \text { - }
$$

го замовлення у $k$-му підрозділі судноремонтного підприємства в періоді $t$, якщо заказ розпочали виконувати у періоді $j$ (кошт. годин);

$$
\begin{array}{r}
Z=\sum_{i=1}^{n} \sum_{k \in K} \sum_{j \in T} \sum_{t \in T} Q_{i j}^{k t} \cdot x_{i j} \rightarrow \max \\
\sum_{i=1}^{n} Q_{i j}^{k t} \cdot x_{i j} \leq T_{k}^{t} ; \forall k=\overline{1 ; m} \\
\sum_{j \in T} \sum_{i \in T} \sum_{i=1}^{n} R_{i j}^{t} \cdot x_{i j} \leq R \\
\sum_{j \in T} x_{i j}=1 ; \forall i \in I_{1} \\
\sum_{j \in T} x_{i j} \leq 1 ; \forall i \notin I_{1} \\
x_{i j} \in\{0 ; 1\} ; \forall i \in I ; \forall j \in T
\end{array}
$$


Постановка задачі планування роботи судноремонтного заводу повинна координуватися 3 плановим ремонтом суден судноплавної компанії. Для вивчення факторів, що впливають на роботу СРП, розглянемо приклад роботи СРП. Така постановка задачі враховує залежність завантаження підприємства від обсягу ресурсів підприємства, обсягу робіт та платоспроможності замовників послуг.

Припустимо, що у плановому річному періоді судноплавної компанії потрібно виконати ремонт частини суден 3 тих, що $є$ у нього: 4 суден типа А i 4 суден типа В. На ремонт одного судна типа А витрачається в середньому 70 діб $(60$ діб заводському та 10 діб у доковому ремонті), а на ремонт одного судна типа В - 45 діб (30 діб у заводському і 15 діб у доковому ремонті). Вартість доби знаходження в ремонті для усіх суден складає 800 доларів у заводському та 1000 доларів у доковому ремонті. Загальні витрати на ремонт суден, які понесені судноплавною компанією, не повинні перевищувати в планованому періоді 300 тис. доларів.

Відомі також норми середньодобової продуктивності в нормо-годинах при заводському та доковому ремонтах по типам суден $\left(\Pi_{i}^{\text {док,ообу }}\right.$,

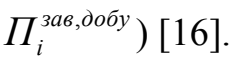

Необхідно скласти план ремонту суден судноплавної компанії, що максимізував би загальну кількість відремонтованих суден.

Норми середньодобової продуктивності, нормо-годин/добу

Таблиия 1

\begin{tabular}{|c|c|c|}
\hline Типи суден & Заводський ремонт, $\Pi_{i}^{\text {зав,добу }}$ & Доковий ремонт, $\Pi_{i}^{\text {док,ообу }}$ \\
\hline $\mathrm{A}$ & 515 & 740 \\
\hline $\mathrm{B}$ & 515 & 830 \\
\hline
\end{tabular}

Джерело: [16]

Будемо використовувати для розрахунків модель (1)-(5).
Для розрахунку витрат одного судна кожного типу підчас ремонту використовується формула:

$$
R_{i}=C_{i}^{\text {sas }} \cdot T_{i}^{\text {зав }}+C_{i}^{\text {док }} \cdot T_{i}^{\text {док }} .
$$

Витрати на ремонт одного судна типа А:

$$
R_{A}=60 * 800+10 * 1000=58000 \text { доларів . }
$$

Витрати на ремонт одного судна типа В:

$$
R_{B}=30 * 800+15 * 1000=39000 \text { доларів }
$$


Обсяг ремонтних робіт для одного судна кожного типу під час до- кового та заводського ремонту розраховується за формулами (13),(14):

$$
\begin{aligned}
& \Pi_{i}^{\text {зав }}=T_{i}^{\text {зав }} \cdot \Pi_{i}^{\text {зав,добу } ;} \\
& \Pi_{i}^{\text {док }}=T_{i}^{\text {док }} \cdot \Pi_{i}^{\text {док, добу }} .
\end{aligned}
$$

Таблиия 2

Обсяг ремонтних робіт судна по видах ремонту (нормо-годин/1 судно)

\begin{tabular}{|c|r|r|}
\hline Типи суден & Заводський ремонт & Доковий ремонт \\
\hline $\mathrm{A}$ & $515 * 60=30900$ & $740 * 10=7400$ \\
\hline $\mathrm{B}$ & $515 * 30=15450$ & $830 * 15=12450$ \\
\hline
\end{tabular}

Джерело: розраховано авторами

Загальний річний обсяг за- приємства розрахуємо за формулою: водського та докового ремонту під-

$$
\begin{gathered}
T^{\text {зав }}=365^{*} \prod_{\text {середня }}^{\text {зав,ообу }}=365 * 515=187975 \text { нормо-годин; } \\
T^{\text {док }}=365^{*} \prod_{\text {середня }}^{\text {до, обу }}=365^{*} 785=286525 \text { нормо-годин. }
\end{gathered}
$$

Нехай $\mathrm{X}_{1}, \mathrm{X}_{2}$ - кількість відремонто-

Математична модель за числованих суден типа $\mathrm{A}$ та типа $\mathrm{B}$ вими даними має вид (15)-(21): відповідно.

$$
\begin{gathered}
Ц \Phi=\mathrm{X}_{1}+\mathrm{X}_{2} \rightarrow \mathrm{MAX} \\
30900 * \mathrm{X}_{1}+15450 * \mathrm{X}_{2} \leq 187975 \\
7400 * \mathrm{X}_{1}+12450 * \mathrm{X}_{2} \leq 286525 \\
58000 * \mathrm{X}_{1}+39000 * \mathrm{X}_{2} \leq 300000 \\
\mathrm{X}_{1} \leq 4 \\
\mathrm{X}_{2} \leq 4 \\
\mathrm{X}_{1} \geq 0, \mathrm{X}_{2} \geq 0
\end{gathered}
$$

Оптимальний план задачі був рішень в EXCEL ( табл.3). розрахований за допомогою пошуку 
DEVELOPMENT OF MANAGEMENT AND ENTREPRENEURSHIP METHODS ON TRANSPORT, № 2 (75), 2021
РОЗВИТОК МЕТОДІВ

УПРАВЛІННЯ ТА ГОСПОДАРЮВАННЯ

НА ТРАНСПОРТІ, № 2 (75), 2021

Табличяя 3

Оптимальний план ремонту суден пароплавства (план1)

\begin{tabular}{|c|c|c|c|c|c|c|}
\hline \multirow{2}{*}{$\begin{array}{l}\text { Параметри } \\
\text { управління }\end{array}$} & \multirow{2}{*}{$\frac{\mathrm{X} 1}{2,48}$} & \multirow{2}{*}{$\frac{X 2}{4}$} & \multicolumn{3}{|c|}{ Обмеження } & \multirow[b]{2}{*}{ Резерви } \\
\hline & & & $\begin{array}{c}\text { Ліва } \\
\text { частина }\end{array}$ & Знак & $\begin{array}{c}\text { Права } \\
\text { частина }\end{array}$ & \\
\hline Обмеження (16) & 30900 & 15450 & 138517,2 & $\leq$ & 187975 & 49457,8 \\
\hline Обмеження (17) & 7400 & 12450 & 68172,4 & $\leq$ & 286525 & 218352,6 \\
\hline Обмеження (18) & 58000 & 39000 & 300000 & $\leq$ & 300000 & 0,00 \\
\hline Обмеження (19) & 1 & & 2,48 & $\leq$ & 4 & 1,52 \\
\hline Обмеження (20) & & 1 & 4 & $\leq$ & 4 & 0,00 \\
\hline Цільова функція (15) & 1 & 1 & 6,48 & \multicolumn{3}{|c|}{ Використання потужності } \\
\hline
\end{tabular}

Джерело: розраховано авторами

В оптимальному плані гроші, виділені судноплавною компанією (18), дозволяють відремонтувати 2,48 судна типу А та 4 суден типу В. Ресурсами, що лімітують процес ремонту, є витрати судноплавної компанії, при чому ресурсів судноремонт- ного заводу достатньо, щоб відремонтувати додаткові судна. Розрахунок виробничої потужності заводу за умовами, коли не враховується обмеження на витрати судноплавної компанії, приведений в табл. 4.

Таблиия 4

Розрахунок річної виробничої спроможності заводу (план2)

\begin{tabular}{|c|c|c|c|c|c|c|}
\hline \multirow{2}{*}{$\begin{array}{l}\text { Параметри } \\
\text { управління }\end{array}$} & $\mathrm{X} 1$ & $\mathrm{X} 2$ & \multicolumn{3}{|c|}{ Обмеження } & \multirow[b]{2}{*}{ Резерви } \\
\hline & 4,00 & 4,17 & $\begin{array}{c}\text { Ліва } \\
\text { частина }\end{array}$ & Знак & $\begin{array}{c}\text { Права } \\
\text { частина }\end{array}$ & \\
\hline Обмеження(16) & 30900 & 15450 & 187975 & $\leq$ & 187975 & 0,00 \\
\hline Обмеження (17) & 7400 & 12450 & 81475 & $\leq$ & 286525 & 205050 \\
\hline Обмеження (19) & 1 & & 4 & $\geq$ & 4 & 0,00 \\
\hline Обмеження (20) & & 1 & 4,17 & $\geq$ & 4 & 0,17 \\
\hline Цільова функція(15) & 1 & 1 & 8,17 & \multicolumn{3}{|c|}{ Виробнича потужність } \\
\hline
\end{tabular}

Джерело: розраховано авторами

В цьому плані знаки в обмеженнях (19), (20) змінені на протилежні ( $\geq$ ), обмеження (18) відсутнє. У такому плані відремонтовані 4 судна типу А та 4,17 суден типу В. Ресур- сом, який лімітує процес ремонту, буде виробнича потужність у заводському ремонті. Запропонований підхід для організації виробництва дозволяє виявити лімітуючи ресурси, які реалі- 
зують ефективний процес ремонту суден. Вирішення цього завдання полягає в першу чергу в складанні, 3 одного боку, реальних здійсненних планів виробництва, а 3 іншого боку планів, що дозволяють найбільшою мірою оптимізувати використання ресурсів підприємства. Формування моделей для розрахунку планів судноремонту дозволяє реалізувати процес вибору найбільш відповідного варіанту при прийнятті управлінських рішень.
Якщо судноплавна компанія виділить більше грошей на ремонт суден, наприклад, 400 тис. доларів, то будуть відремонтовані усі 4 судна типу А та 4 судна типу В. При збільшенні платоспроможності судноплавної компанії ресурсом, який лімітує процес ремонту, будуть забезпечені обсяги ремонту, виражені заданою кількістю суден типу А. Розрахунки показані у табл. 5.

Таблиия 5

Влив платоспроможності пароплавства на оптимальний план ремонту (план3)

\begin{tabular}{|c|c|c|c|c|c|}
\hline \multirow[b]{2}{*}{ Умови моделі } & \multirow{2}{*}{$\frac{X 1}{4,00}$} & \multirow{2}{*}{$\frac{X 2}{4,17}$} & \multicolumn{2}{|c|}{ Обмеження } & \multirow[b]{2}{*}{ Резерви } \\
\hline & & & $\begin{array}{c}\text { Ліва } \\
\text { частина }\end{array}$ & $\begin{array}{c}\text { Права } \\
\text { частина }\end{array}$ & \\
\hline Обмеження (16) & 30900 & 15450 & 185400 & 187975 & 2575,00 \\
\hline Обмеження (17) & 7400 & 12450 & 79400 & 286525 & 207125,00 \\
\hline Обмеження (18) & 58000 & 39000 & 388000 & 400000 & 12000,00 \\
\hline Обмеження (19) & 1 & & 4 & 4 & 0,00 \\
\hline Обмеження (20) & & 1 & 4 & 4 & 0,00 \\
\hline Цільова функція(15) & 1 & 1 & 8 & Викорис & потужності \\
\hline
\end{tabular}

Джерело: розраховано авторами

Іншими факторами, які можуть впливати на ефективність ремонту, являються продуктивність та організація праці в процесі ремонту. Відомо, що використання бригадної форми праці може зменшити час ремонту суден шляхом зменшення невиробничих витрат часу. У табл. 6 показані зміни нормативів часу на ремонт та витрат на одне судно у вихідних умовах та з використанням бригадної форми праці. У табл. 7 розрахована виробнича потужність ремонту, яка збільшилась до 9,8 суден завдяки використанню бригадної форми організації праці, що зменшує строки ремонту суден.

У проведених розрахунках контрольного прикладу було отримано чотири оптимальних плани $з$ різними умовами оптимізації: 
- план 1 - використання виробничої потужності СРП із заданими початковими даними;

- план 2 - 3 максимальною виробничою потужністю при повному використанні ресурсів СРП;
- план 3 - при зміні платоспроможності судноплавної компанії;

- план 4 - при зміні нормативів використання ресурсів та строків ремонту суден. У всіх планах проаналізований обсяг ремонту та наявність ресурсів, що лімітують виробничий процес.

Таблиия 6

Нормативи ремонту 1 судна

\begin{tabular}{|l|c|c|c|c|}
\hline \multirow{2}{*}{ Найменування нормативів } & \multicolumn{4}{|c|}{ Умови організації праці } \\
\cline { 2 - 5 } & \multicolumn{2}{|c|}{ Вихідні умови } & \multicolumn{2}{|c|}{ Бригадна форма } \\
\hline Типи суден & Тип А & Тип В & Тип А & Тип В \\
\hline Продуктивність заводського ремонту & 515 & 515 & 515 & 515 \\
\hline Продуктивність докового ремонту & 740 & 830 & 740 & 830 \\
\hline Час заводського ремонту (діб) & 60 & 30 & 55 & 25 \\
\hline Час докового ремонту (діб) & 10 & 15 & 10 & 15 \\
\hline Витрати на 1 судна (долари) & 58000 & 39000 & 54000 & 35000 \\
\hline $\begin{array}{l}\text { Обсяги заводського ремонту судна } \\
\text { (нормо-годин) }\end{array}$ & 30900 & 15450 & 28325 & 12875 \\
\hline $\begin{array}{l}\text { Обсяги докового ремонту судна } \\
\text { (нормо-годин) }\end{array}$ & 7400 & 12450 & 7400 & 12450 \\
\hline
\end{tabular}

Джерело: розраховано авторами з використанням [16]

Таблиия 7

Вплив часу ремонту на оптимальний план ремонту (план4)

\begin{tabular}{|l|c|c|c|c|r|}
\hline \multirow{2}{*}{ Умови моделі } & $\mathrm{X} 1$ & $\mathrm{X} 2$ & \multicolumn{2}{|c|}{ Обмеження } & \multirow{2}{*}{ Резерви } \\
\cline { 2 - 5 } & 4,00 & 5,80 & $\begin{array}{c}\text { Ліва } \\
\text { частина }\end{array}$ & $\begin{array}{c}\text { Права } \\
\text { частина }\end{array}$ & \\
\hline Обмеження(16) & 28325 & 12875 & 187975 & 187975 & 0,00 \\
\hline Обмеження (17) & 7400 & 12450 & 101810 & 286525 & 184715,0 \\
\hline Обмеження (18) & 54000 & 35000 & 419000 & 500000 & 81000,0 \\
\hline Обмеження (19) & 1 & & 4 & 4 & 0,00 \\
\hline Обмеження (20) & & 1 & 5,80 & 4 & 1,80 \\
\hline Цільова функція (15) & 1 & 1 & 9,80 & Виробнича потужність \\
\hline
\end{tabular}

Джерело: розраховано авторами 
Висновки. На підставі запропонованих моделей можна виділити наступні групи факторів, від яких залежить використання виробничої потужності СРП:

1) техніко-експлуатаційні параметри підрозділів СРП (обмеження (2));

2) попит на послуги СРП у вигляді обсягів планових робіт за видами виробничої діяльності (обмеження (3));

3) нормативи використання потужностей СРП;

4) платоспроможність замовників (обмеження (4));

5) спосіб організації виробничого процесу.

Використовуючи метод елімінування, можна визначити вплив різних факторів на виробничу потужність СРП, змінюючи по черзі різні фактори, представлені у моделі.

Під способом організації будемо розуміти закріплення тих чи інших ресурсів підрозділів СРП за виконанням планових або додаткових замовлень. Тобто вплив техніко-експлуатаційних характеристик, нормативів використання ресурсів, зовнішніх факторів на ринку судноремонту відображається обсягом судноремон- ту та іншими показниками виробничої програми при фактичному або оптимальному способі організації виробництва.

Слід відзначити, що п'яту групу факторів: спосіб організації виробничого процесу - можна вважати системоутворювальною, тому що вплив інших факторів визначається при тому чи іншому способі організації (фактичному або оптимальному).

Розрахунки на підставі ускладненої моделі з використанням цілочисельного та динамічного програмування дозволять розподілити ресурси СРП між замовленнями по місяцях року $з$ метою досягнення рівномірного завантаження потужностей, що може бути предметом наступних досліджень. Найважливішим результатом оптимізації використання виробничої потужності СРП є визначення ресурсів підприємства або зовнішніх факторів ринку, які лімітують виробничий процес, що характеризує співвідношення між попитом на послуги та пропозицією цих послуг на ринку судноремонту. Інформація про ринкові чинники виробництва також необхідна для задач розвитку підприємств і може впливати на перспективні плани роботи СРП.

\section{СПИСОК ЛІТЕРАТУРИ}

1. Колесникова О.В. Исследование и разработка процессно-ориентированной технологи технологии подготовки дискретного производства в судоремонте. Диссертация на соискание ученой степени кандидата технических наук. Владивосток, 2015. 191 c. URL: https://www.msun.ru/upload/ dis/kolesnikova.pdf

2. Пашеева Т.Ю., Конарев П.М. Судоремонт Мурманска: состояние и перспективы. Вестник АГТУ. Сер.: Морская техника и технология. 2021. № 1. C. $24-30$ 
3. Власов С.В. Разработка методов планирования и организации управления судоремонтным предприятием на основе технологий многофакторной модели производственной функции. Автореферат дис...канд.екон.наук. Владивосток. 2014. 23 с. URL: https://www.dissercat.com/content/razrabotkametodov-planirovaniya-i-organizatsii-upravleniya-sudoremontnym-predpriyatiem-na-o

4. Catia Antunes. European shipbuilding and ship repairs outside Europe: Problems, questions and some hypotheses // International journal of maritime history. 2019. URL: https://doi.org/10.1177/0843871419860691

5. Robert Casrillon Dussan. Republic of Colombia. Ship repairs competition: driver and opportunities. A dissertation submitted to the World Maritime University in partial fulfilment of the requirements for the award of the degree of Master of science in Maritime affairs (port management). 2007. URL: https://commons.wmu.se/cgi/viewcontent.cgi?article $=1353 \&$ context $=$ all disser tations

6. Shiprepears business analysis of the Indonesian shipyards. By Dr. Ir. Buana Ma'ruf, M.Sc., MM Agency for the Assessment and Application of Technology, The Republic of Indonesia. The 4th PPM National Conference on Management Research Jakarta, 25 November 2010. URL: https://www. researchgate.net/publication/325284534_SHIP_REPAIR_BUSINESS_ANALYSIS_OF THE_INDONESIAN_SHIPYARDS

7. Кибиткин А.И., Турчанинова Т.В. Оценка портфеля заказов исполнителя судоремонтных работ на основе трудового баланса // Экономические и социальные перемены: факты, тенденции, прогноз. 3 (21), 2012. С.107118.

8. Мартынов Л.В., Кошарская Л.В. Производственный потенциал судоремонтных предприятий и методы оценки эффективности его использования // Вісник Одеського національного морського університету № 2(51). Одеса, 2017. С.142-148.

9. Солодухин К. С.. Совершенствование планирования снижения затрат на судоремонтных предприятиях (На примере ОАО «Находкинский судоремонтный завод»): Дис. ... канд. экон. наук : 08.00.05. Владивосток, 2003. 220 с. РГБ ОД, 61:03-8/3555-6. URL: https://www.dissercat.com/ content/ sovershenstvovanie-planirovaniya-snizheniya-zatrat-na-sudoremontnykh-predpriyatiyakh-na-prim

10. Матушевская Е. А. Оценка экономической устойчивости судоремонтных предприятий Севастополя в современных условиях хозяйствования // БІЗНЕСІНФОРМ. № 6, 2014. С. 253-256.

11. Мартынов Л.В., Махуренко Г.С. Основы расчета производственной мощности судоремонтного предприятия. Тексты лекций. ОИИМФ.1976. 40c.

12. Махуренко Г.С. Моделирование развития и производственной деятельности морского пароходства... Диссертация на соискание ученой степени доктора экономических наук. Одесса 1990. 358 с. 
13. Дмитриев Н.Е., Халиф А.И. Алгоритм составления производственной программы судоремонтного завода // Сб. научн. тр. ЦННИМФ. Л.: Транспорт, вып. 107, 1969. С.10-25. URL: https://naukaprava.ru>catalog

14. Леонов А.А., Леонова Т.М. Модель оптимизации ремонта судов по ремонтным базам. Весник АГТУ. Сер.: Экономика. 2014 №4. С.62-68. URL: https://cyberleninka.ru/article/n/model-optimizatsii-remonta-sudov-poremontnym-bazam/viewer

15. Dongsu Jeong, Dohyun Kim, Taihun Choi and Yoonho Seo. A Process-Based Modeling Method for Describing Production Processes of Ship Block Assembly Planning // Department of Industrial and Management Engineering, Korea University, Published: 21 July 2020 Processes 2020, 8, 880. URL: https://www.mdpi.com/2227-9717/8/7/880

16. Леонов А. А., Щербина Т. М. Экономика, организация и планирование судоремонта: методические указания по выполнению практических работ для студентов направления подготовки 7.050208 «Транспортный менеджмент». Одесса, 1998. 34 с.

\section{REFERENCES}

1. Kolesnikova O.V. (2015). Issledovaniye i razrabotka protsessno-oriyentirovannoy tekhnologi tekhnologii podgotovki diskretnogo proizvodstva $\mathrm{v}$ sudoremonte [Research and development of a process-oriented technology for the preparation of discrete production in ship repair.]. Dissertatsiya na soiskaniye uchenoy stepeni kandidata tekhnicheskikh nauk. Vladivostok, 191p. [in Russian]

2. Pasheyeva T.YU. \& Konarev P.M. (2021). Sudoremont Murmanska: sostoyaniye i perspektivy [Murmansk ship repair: state and prospects]. Vestnik AGTU. Ser.: Morskaya tekhnika i tekhnologiya - Marine engineering and technology. № 1. P. 24-30. [in Russian]

3. Vlasov S.V. (2014). Razrabotka metodov planirovaniya i organizatsii upravleniya sudoremontnym predpriyatiyem na osnove tekhnologiy mnogofaktornoy modeli proizvodstvennoy funktsii [Development of methods for planning and organizing management of a ship repair enterprise based on the technologies of a multifactor model of production function]. Avtoreferat dis...kand. yekon. nauk. Vladivostok. 23 p. [in Russian]

4. Catia Antunes (2019). European shipbuilding and ship repairs outside Europe: Problems, questions and some hypotheses/ International journal of maritime history.

5. Robert Casrillon Dussan (2007). Republic of Colombia. Shiprepears competition: driver and opportunities. A dissertation submitted to the World Maritime University in partial fulfilment of the requirements for the award of the degree of Master of science in Maritime affairs (port management).

6. Shiprepears business analysis of the Indonesian shipyards. (2010) By Dr. Ir. Buana Ma'ruf, M.Sc., MM Agency for the Assessment and Application of 
Technology, The Republic of Indonesia. The 4th PPM National Conference on Management Research Jakarta, 25 November 2010. Retrieved from: https://www.researchgate.net/publication/325284534_SHIP_REPAIR_BUSIN ESS ANALYSIS OF THE INDONESIAN SHIPYARDS

7. Kibitkin A.I. \& Turchaninova T.V. (2012). Otsenka portfelya zakazov ispolnitelya sudoremontnykh rabot na osnove trudovogo balansa [Assessment of the order book of the ship repair contractor based on the labor balance ]/ Ekonomicheskiye i sotsial'nyye peremeny: fakty, tendentsii, prognoz [Economic and social changes: facts, trends, forecast], 3 (21). P.107-118 [in Russian]

8. Martynov L.V. \& Kosharskaya L.V. (2017). Proizvodstvennyy potentsial sudoremontnykh predpriyatiy i metody otsenki effektivnosti yego ispol'zovaniya [The production potential of ship repair enterprises and methods for assessing the effectiveness of its use ]. Vísnik Odes'kogo natsíonal'nogo mors'kogo uníversitetu - Visnik of the Odessa National Maritime University. № 2(51). Odesa. P.142-148 [in Russian]

9. Solodukhin, K. S. (2003) Sovershenstvovaniye planirovaniya snizheniya zatrat na sudoremontnykh predpriyatiyakh (Na primere OAO "Nakhodkinskiy sudoremontnyy zavod") [Improving the planning of cost reduction at ship repair enterprises (on the example of JSC «Nakhodka ship repair plant»]: Dis. ... kand. ekon. nauk: 08.00.05. Vladivostok, 220p. RGB OD, 61:03-8/3555-6 [in Russian]

10. Matushevskaya ,Ye. A. (2014). Otsenka ekonomicheskoy ustoychivosti sudoremontnykh predpriyatiy Sevastopolya v sovremennykh usloviyakh khozyaystvovaniya [Assessment of the economic sustainability of the ship repair enterprises of Sevastopol in modern economic conditions]. BÍZNESÍNFORM. № 6. P.253 - 256[in Russian]

11. Martynov, L.V. \& Makhurenko, G.S. (1976). Osnovy rascheta proizvodstvennoy moshchnosti sudoremontnogo predpriyatiya. Teksty lektsiy.[The basics of calculating the production capacity of a shipyard. Lecture texts]. OIIMF. $40 \mathrm{p}$. [in Russian]

12. Makhurenko, G.S. (1990). Modelirovaniye razvitiya i proizvodstvennoy deyatel'nosti morskogo parokhodstva [Modeling the development and production activities of a shipping company ]... Dissertatsiya na soiskaniye uchenoy stepeni doktora ekonomicheskikh nauk. Odessa. 358p. [in Russian]

13. Dmitriyev, N.Ye. \& Khalif, A.I. (1969). Algoritm sostavleniya proizvodstvennoy programmy sudoremontnogo zavoda [Algorithm for drawing up a production program for a shipyard]. Sb. nauchn. tr. TSNNIMF. L. Transport, vyp.107, P.10-25. [in Russian]

14. Dongsu Jeong, Dohyun Kim, Taihun Choi \& Yoonho Seo (2020). A ProcessBased Modeling Method for Describing Production Processes of Ship Block Assembly Planning. Department of Industrial and Management Engineering, Korea University, Published: 21 July 2020 Processes, 8, 880. 
15. Leonov, A.A. \& Leonova, T.M. (2014). Model' optimizatsii remonta sudov po remontnym bazam. [Ship repair optimization model for repair bases ]Vesnik AGTU.Ser.: Ekonomika, №4. P.62-68 [in Russian]

16. Leonov, A.A. \& Shcherbina, T.M. (1998). Ekonomika, organizatsiya i planirovaniye sudoremonta: metodicheskiye ukazaniya po vypolneniyu prakticheskikh rabot dlya studentov napravleniya podgotovki 7.050208 [Economics, organization and planning of ship repair: guidelines for the implementation of practical work for students in the field of training] «Transportnyy menedzhment». Odessa, 34 p. [in Russian]

\section{Стаття надійшла 28.05.2021}

Посилання на статтю: Гіріна О.Б., Жигаловська С.О. Оптимізація використання виробничої потужності судноремонтного підприємства // Розвиток методів управління та господарювання на транспорті: Зб. наук. праць, 2021. № 2 (75). C. 89-107. DOI 10.31375/2226-1915-2021-2-89-107.

Article received 28.05.2021

Reference a JournalArtic: Girina, Olga \& Zhigalovskaya, Svetlana (2021). Optimization of the use of the production capacity of a shipyard. Development of management and entrepreneurship methods on transport. 2 (75), 89-107. DOI 10.31375/2226-1915-2021-2-89-107. 